\title{
Designing A 3-Dimensional Campus Brochure Application Based On Augmented Reality
}

\author{
(Perancangan Aplikasi Brosur Kampus 3-Dimensi Berbasis Augmented Reality)
}

\author{
Liza Angriani ${ }^{1}$, Abd. Rachman Dayat ${ }^{2 *}$ \\ ${ }^{1}$ Program Studi Manajemen Informatika, ${ }^{2}$ Program Studi Ilmu Komputer \\ Sekolab Tinggi Manajemen dan Imu Komputer Umel Mandiri \\ Jn. Raya Abepura Kotaraja Jayapura Papua 99351
}

\section{ABSTRACT}

STMIK Umel Mandiri as one of the universities in Jayapura is still less well known, apart from being relatively new in its age and the location of the campus building which is blocked by buildings. So that people sometimes do not know the exact location of the campus. To promote the campus, one of the advertising media used is brochures. Along with current technological developments, augmented reality technology has emerged which is able to combine 2 (two) realities, namely the real and virtual world. When used in brochures, it can provide a feel and experience for readers. So that promoting goods or services can be done more interactively, as well as providing more information to consumers about the product. This augmented reality technology is then used as a solution to the problems faced by STMIK Umel Mandiri in promoting its educational institutions. The purpose of this research is to produce an android application that can display a 3 (three) dimensional brochure model by utilizing augmented reality technology so that it can help the public to get to know the campus to be chosen well. The research method has several stages, namely collecting data about the needs of prospective new students regarding information about the STMIK Umel Mandiri campus, then making a 3 (three) dimensional model of the STMIK Umel Mandiri Campus Building. Then next, do the design of compatible augmented reality on smartphone devices using the Android operating system, and produce 3 (three) dimensional augmented reality objects. This research produces an application based on augmented reality technology that is used to help promote the STMIK Umel Mandiri Campus through devices with the android operating system.

STMIK Umel Mandiri sebagai salah satu perguruan tinggi di Jayapura masih kurang dikenal, selain karena usianya masih terbilang baru dan juga lokasi gedung kampus yang terhalang bangunan. Sehingga masyarakat kadang tidak mengetahui lokasi kampus secara pasti. Untuk mempromosikan kampus salah satu media iklan yang digunakan adalah brosur. Seiring perkembangan teknologi saat ini, muncul teknologi angmented reality yang mampu menggabungkan 2 (dua) realitas yakni dunia nyata dan maya. Apabila digunakan dalam brosur, maka mampu memberikan feel dan experience bagi pembaca. Sehingga mempromosikan barang atau jasa dapat dilakukan dengan lebih interaktif, serta memberikan informasi yang lebih kepada konsumen terhadap produk. Teknologi augmented reality ini yang dimanfaatkan untuk dijadikan solusi dari permasalahan yang dihadapi oleh STMIK Umel Mandiri dalam melakukan promosi instansi pendidikannya. Tujuan dari penelitian ini adalah untuk menghasilkan sebuah aplikasi android yang dapat menampilkan model brosur 3 (tiga) dimensi dengan memanfaatkan teknologi augmented reality sehingga dapat membantu masyarakat untuk mengenal dengan baik kampus yang akan dipilih. Metode penelitian memiliki beberapa tahapan yaitu pengumpulan data tentang kebutuhan calon mahasiswa baru mengenai informasi seputar kampus STMIK Umel Mandiri, kemudian membuat model 3 (tiga) dimensi dari Gedung Kampus STMIK Umel Mandiri. Kemudian selanjutnya, melakukan perancangan angmented reality yang kompatibel pada perangkat smartphone yang menggunakan sistem operasi android, serta menghasilkan objek 3 (tiga) dimensi augmented reality. Penelitian ini menghasilkan sebuah aplikasi berbasis teknologi augmented reality yang digunakan untuk membantu mempromosikan Kampus STMIK Umel Mandiri melalui perangkat dengan sistem operasi android.

Keywords: android, augmented reality, 3-dimensional. 


\section{PENDAHULUAN}

Salah satu sarana untuk mempromosikan usaha adalah iklan. Melakukan promosi melalui media televisi, radio, majalah, maupun koran hanya memberikan pesan satu arah dari produsen kepada konsumen tanpa ada interaksi dan feedback langsung dari konsumen. Kemajuan di bidang teknologi informasi saat ini mampu menciptakan inovasi dalam dunia periklanan. Di mana awalnya hanya berupa banner digital pada website, hingga yang terkini dengan menerapkan teknologi Augmented Reality (AR) yaitu teknologi yang memunculkan benda maya 2 (dua) dimensi maupun 3 (tiga) dimensi ke dalam sebuah lingkungan nyata, sehingga benda/objek tersebut terasa ada dan nyata. Apabila digunakan dalam media periklanan, maka lebih menambahkan feel dan experience tersendiri bagi calon konsumen suatu produk/layanan. Calon konsumen tersebut secara langsung diajak untuk merasakan dan mendapatkan pengalaman saat menggunakan produk sebelum menggunakan produk nyatanya. Sehingga beriklan dapat dilakukan dengan lebih interaktif dan mampu menciptakan hubungan yang erat antara konsumen dengan produk. Kelebihan dari teknologi augmented reality inilah yang ingin dijadikan solusi atas permasalahan yang dihadapi oleh STMIK Umel Mandiri dalam melakukan promosi instansi pendidikannya.

Keberadaan STMIK Umel Mandiri sebagai salah satu perguruan tinggi di Jayapura masih kurang dikenal, selain karena usianya masih terbilang baru dan juga lokasi gedung kampus yang terhalang bangunan, sehingga masyarakat kadang tidak mengetahui lokasi kampus secara pasti. Untuk mempromosikan kampus, salah satu media iklan yang digunakan adalah brosur yang merupakan media yang masih konvensional, namun ternyata media ini masih familiar dan banyak dilakukan pelaku usaha karena sebagian orang menganggap brosur masih menjadi sumber informasi yang berguna. Meskipun informasi sudah tersedia melalui website kampus, tetapi brosur telah membuktikan dirinya masih menjadi bagian penting dalam industri pemasaran, khususnya di kota Jayapura yang masih tergolong rendah dalam memanfaatkan teknologi internet.

Selama ini penyebaran brosur dilakukan bersamaan dengan kegiatan sosialisasi kampus ke sekolahsekolah, hasil yang didapat kurang memuaskan, sehingga dibutuhkan upaya dalam meningkatkan nilai dan kualitas brosur untuk memperkenalkan STMIK Umel Mandiri dengan informasi yang lebih detail. Dengan adanya perkembangan teknologi smartphone yang belakangan ini semakin meningkat, media iklan mendapat dukungan tanpa harus meninggalkan bentuk konvensional dengan memanfaatkan teknologi augmented reality.

Oleh karena itu, pemanfaatan teknologi augmented reality dalam perancangan aplikasi brosur kampus 3 (tiga) dimensi pada media promosi di STMIK Umel Mandiri diharapkan mampu membantu masyarakat mengenal lebih dekat Kampus STMIK Umel Mandiri dengan cara yang lebih interaktif.

Berdasarkan latar belakang tersebut, dapat dirumuskan permasalahan yaitu bagaimana memanfaatkan teknologi augmented reality dalam perancangan aplikasi brosur kampus 3 (tiga) dimensi.

Tujuan dari penelitian ini adalah untuk menghasilkan sebuah aplikasi android yang dapat menampilkan model brosur 3 (tiga) dimensi dengan memanfaatkan teknologi augmented reality sehingga dapat membantu masyarakat untuk mengenal dengan baik kampus yang akan dipilih.

Urgensi penelitian ini bukan hanya dapat melihat bagian brosur angmented reality dengan detail, tetapi lingkungan pada brosur juga akan terasa lebih nyata dengan adanya animasi pendukung seperti gedung, pohon, dan lain sebagainya, sehingga diharapkan dapat membantu para pembaca untuk mengetahui dengan baik kampus yang akan dipilih.

\section{Tinjauan Pustaka \\ Augmented Reality}

Menurut Ronald T. Azuma pada tahun 1997, augmented reality (AR) adalah menggabungkan dunia nyata dan virtual, bersifat interaktif secara real time, dan merupakan animasi 3 (tiga) Dimensi (3D). Sejarah tentang AR dimulai dari tahun 1957 - 1962, ketika seorang penemu yang bernama Morton Heilig, seorang sinematografer, menciptakan dan mempatenkan sebuah simulator yang disebut Sensorama dengan visual, getaran, dan bau. Pada tahun 1966, Ivan Sutherland menemukan headmounted display yang dia claim adalah, jendela ke dunia virtual [1].

Tahun 1975 seorang ilmuwan bernama Myron Krueger menemukan Videoplace yang memungkinkan pengguna, dapat berinteraksi dengan objek virtual untuk pertama kalinya. Tahun 1989, 
Jaron Lanier, memperkenalkan Virtual Reality dan menciptakan bisnis komersial pertama kali di dunia maya dan pada tahun 1992 mengembangkan AR untuk melakukan perbaikan pada pesawat boeing. Pada tahun yang sama LB Rosenberg mengembangkan salah satu fungsi sistem AR yang disebut Virtual Fixtures, yang digunakan di Angkatan Udara AS Armstrong Labs dan menunjukan manfaatnya pada manusia. Pada tahun 1992 juga, Steven Feiner, Blair Maclntyre, dan dorée Seligmann, memperkenalkan untuk pertama kalinya Major Paper untuk perkembangan Prototype AR [1].

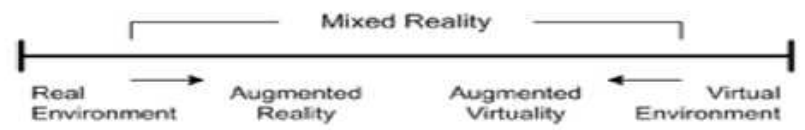

Gambar 1. Virtuality Continum oleh Milgram dan Kishino [1].

Pada tahun 1994, Milgram dan Kishino merumuskan kerangka kemungkinan penggabungan dan peleburan dunia nyata dan dunia maya ke dalam sebuah kontinuum virtualitas.

Sisi yang paling kiri adalah lingkungan nyata yang hanya berisi benda nyata, dan sisi paling kanan adalah lingkungan maya yang berisi benda maya [2].

Dalam realitas tertambah, yang lebih dekat ke sisi kiri, lingkungan bersifat nyata dan benda bersifat maya, sementara dalam augmented virtuality atau virtualitas tertambah, yang lebih dekat ke sisi kanan, lingkungan bersifat maya dan benda bersifat nyata. Realitas tertambah dan virtualitas tertambah digabungkan menjadi mixed reality atau realitas campuran.

Salah satu bentuk teknologi yang berkembang sekarang adalah AR. Perkembangan teknologi AR saat ini telah memberikan banyak kontribusi ke dalam berbagai bidang. Bidang-bidang tersebut meliputi periklanan dan pemasaran, arsitektur dan konstruksi, hiburan, medis, militer, serta perjalanan wisata. AR yaitu realita yang ditambahkan ke suatu media [3]. Teknologi AR ini berbeda dengan teknologi Virtual Reality. AR berarti kebalikan dari Virtual Reality berupa integrasi elemen-elemen digital yang ditambahkan ke dalam dunia nyata secara realtime, interaktif, dan mengikuti keadaan lingkungan yang ada di dunia nyata.

AR adalah sebuah bidang penelitian komputer yang berhubungan dengan kombinasi antara dunia nyata dengan data hasil rekayasa komputer. Istilah ini muncul pertama kali pada tahun 1990 ketika Tom Caudell dan David Mizell mendesain suatu head set display disebut HUDset (HeadsUp, see-through, headmounted Display) yang dapat menampilkan skematik diagram wiring pesawat dan berbagai instruksinya untuk Boeing sehingga dalam proses manufacturing, teknisi Boeing tidak perlu lagi membawa instruction manual dan skematik diagram [4]. Azuma mendifinisikan AR sebagai sistem yang menggabungkan nyata dan virtual, interaktif dalam realtime dan register dalam $3 \mathrm{D}$. Inti dari AR merujuk pada penjelasan Dorfmuller dan Zlatanova adalah melakukan interfacing untuk menempatkan objek virtual ke dalam dunia nyata. Sistem AR memiliki tiga komponen utama. Tracking system menentukan posisi dan orientasi objek-objek dalam dunia nyata. Graphic system menggunakan informasi yang disediakan tracking system untuk menggambarkan gambar-gambar virtual pada tempat yang sesuai, sebagai contoh melalui objek-objek nyata.

Tampilan sistem menggabungkan dunia nyata dengan gambar virtual dan mengirimkan hasilnya ke pengguna, misalkan dikirim ke HMD, tetapi tampilan biasa juga seperti monitor dapat digunakan [3], [5], [8], dan [9].

\section{Brosur}

Brosur merupakan salah satu media promosi yang sering digunakan untuk memberikan penjelasan tentang suatu produk, layanan, fasilitas umum, profil perusahaan, sekolah, atau dimaksudkan sebagai sarana untuk beriklan.

STMIK Umel Mandiri menggunakan brosur sebagai salah satu media promosi yang digunakan untuk menyebarkan informasi kepada masyarakat yang ingin melanjutkan studi khususnya di bidang Infomatika dan Komputer.

\section{Android}

Android adalah sebuah sistem operasi untuk perangkat mobile berbasis Linux yang mencakup sistem operasi, middleware, dan aplikasi. Android menyediakan platform terbuka bagi para pengembang buat menciptakan aplikasi sendiri. Android dipuji sebagai "platform mobile pertama yang lengkap, terbuka, dan bebas".

1. Lengkap (Complete Platform): Android merupakan sistem operasi yang aman dan banyak 
menyediakan tools dalam membangun software dan memungkinkan untuk pengembangan aplikasi.

2. Terbuka (Open Source Platform): Platform android disediakan melalui lisensi open source. Pengembang dapat dengan bebas mengembangkan aplikasi.

3. Bebas (Free Platform): Android adalah aplikasi yang bebas untuk develop. Tidak ada lisensi atau biaya royalty untuk dikembangkan pada platform android.

Pengembang memiliki beberapa pilihan ketika membuat aplikasi yang berbasis android. Sebagain besar pengembang menggunakan Eclipse. Eclipse adalah IDE yang paling popular untuk pengembangan android, karena memiliki android plug-in yang tersedia untuk memfasilitasi pengembangan android [5].

Saat ini disediakan Android SDK (Software Development Kit) yaitu tools API (Application Programming Interface) untuk mulai pengembangkan aplikasi pada platform android atau dapat dikatakan sebagai perangkat lunak yang digunakan dalam pengembangan aplikasi pada android [6],[7], dan [10].

\section{METODE PENELITIAN}

Metode penelitian AR Brosur 3D ini menggunakan Marker Based Tracking dimana ada beberapa tahap yang perlu dipersiapkan yaitu pengumpulan data tentang kebutuhan calon mahasiswa baru akan informasi mengenai kampus STMIK Umel Mandiri, kemudian membuat model 3 (tiga) dimensi dari Gedung Kampus STMIK Umel Mandiri. Tahap selanjutnya adalah merancang sistem augmented reality yang dapat berjalan pada device dengan system operasi android serta memunculkan obyek 3 (tiga) dimensi dalam bentuk angmented reality.

Tahapan penelitian yang dilakukan dimulai dari awal pengerjaan hingga akhir penelitian digambarkan pada Gambar 2.

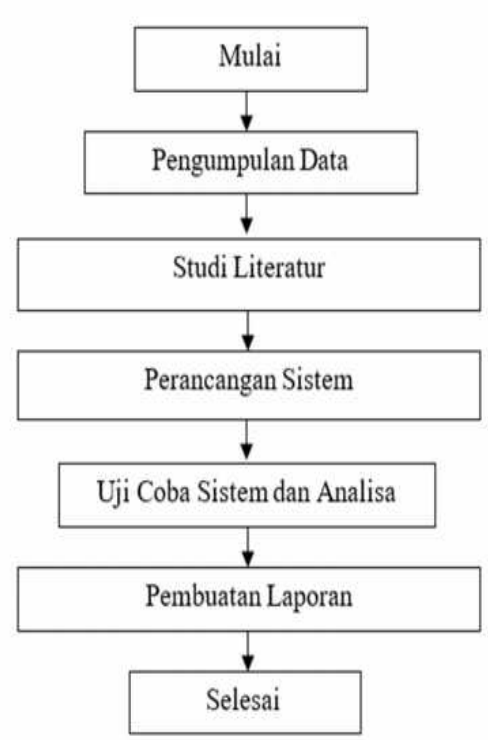

Gambar 2. Diagram Alir Penelitian

Rancangan penelitian yang dikembangkan pada penelitian ini dapat dilihat pada Gambar 3.

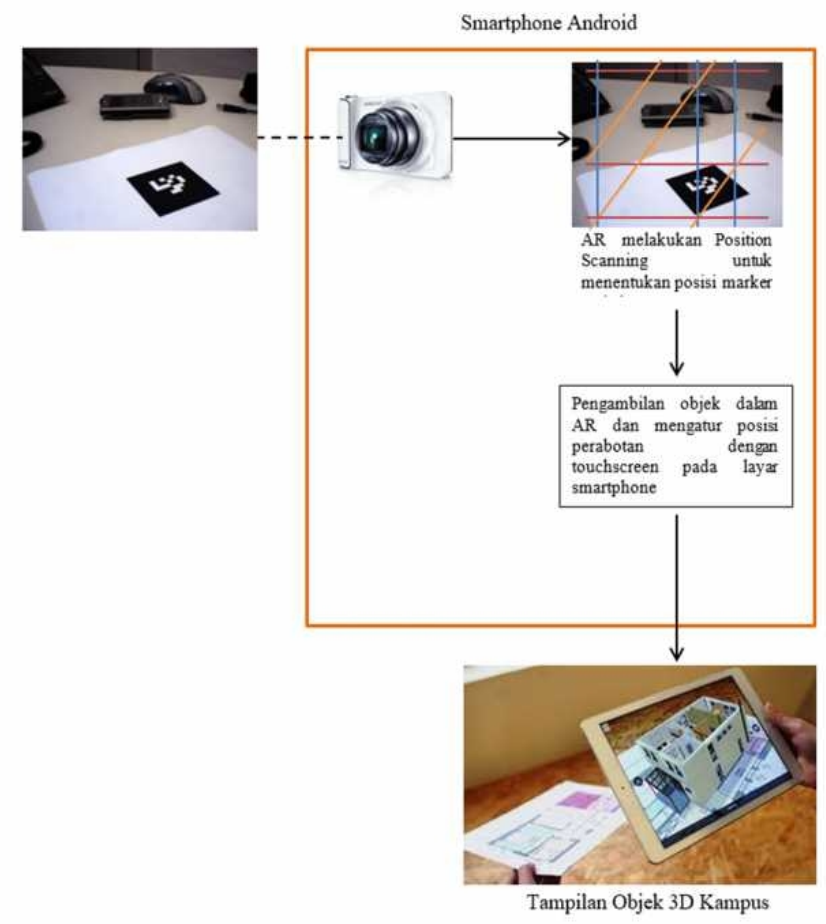

Gambar 3. Rancangan Penelitian. 


\section{HASIL DAN PEMBAHASAN}

\section{Analisis Sistem}

Dalam analisis ini dibahas tentang yang dibutuhkan dalam sistem aplikasi yang dibuat

1. Spesifikasi Perangkat Lunak

Aplikasi untuk brosur AR diberi nama STMIK Umel Mandiri menggunakan bahasa pemrograman C\# dengan memanfaatkan software Unity3D, SDK Vuforia, dan SDK Android. Bahasa pemrogaman C\# dipilih karena bahasa pemrograman ini cukup baik untuk mengembangkan aplikasi mobile android kemudian dibangun dengan unity dan library EasyAR untuk membangun aplikasi AR STMIK Umel Mandiri.

2. Fungsional Sistem

Aplikasi STMIK Umel Mandiri ini dapat diakses oleh multi pengguna pada markernya, di mana pengguna tersebut menjalankan aplikasi ini menggunakan marker yang merupakan brosur fisik melalui perangkat mobile android yang sudah memiliki aplikasi AR. Adapun marker yang digunakan dapat dilihat pada Gambar 4.

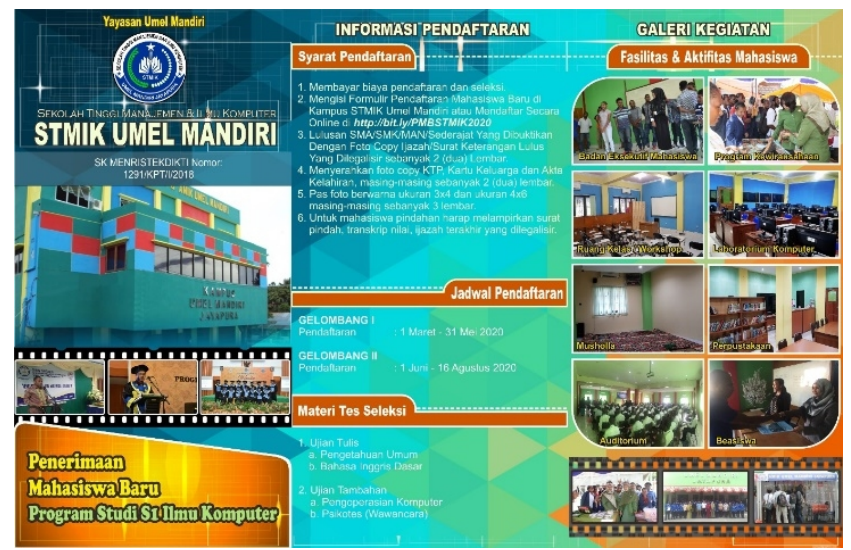

Gambar 4. Marker Aplikasi AR Brosur STMIK Umel Mandiri

\section{Cara Kerja Sistem}

Ketika pertama kali aplikasi AR brosur STMIK Umel Mandiri dijalankan, splash screen akan ditampilkan. kemudian aplikasi akan mengarahkan pengguna ke menu utama aplikasi. Berikut adalah tahapan kerja sistem secara keseluruhan.

1. Intro Aplikasi

Splash screen merupakan bagian intro dari aplikasi AR brosur STMIK Umel Mandiri dengan menampilkan logo aplikasi AR. Tampilan splash screen dapat dilihat pada Gambar 5.

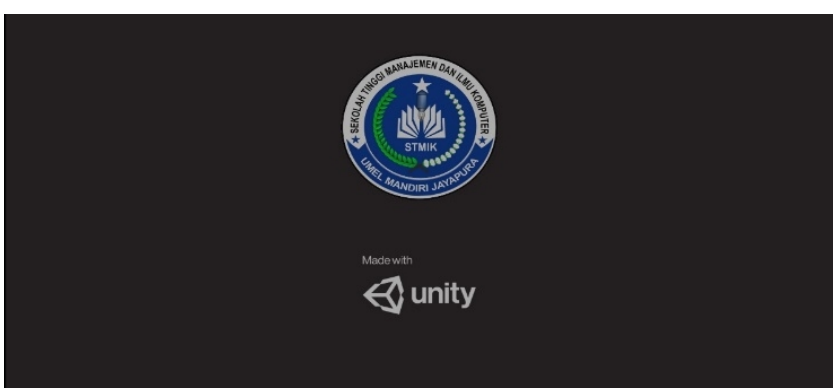

Gambar 5. Splash Screen AR Brosur STMIK Umel Mandiri

Setelah splash screen dimunculkan, aplikasi AR brosur STMIK Umel Mandiri akan menampilkan tampilan utama.

2. Tahapan Tampilan Menu Utama

Tampilan menu utama merupakan tahapan untuk memulai menggunakan aplikasi AR brosur STMIK Umel Mandiri, di mana sebelum menampilkan 3D objek gedung STMIK Umel Mandiri, pengguna dapat memilih menu yang tersedia, antara lain AR, Visi Misi, About dan Link menuju website kampus STMIK Umel Mandiri. Tampilan menu utama dapat dilihat pada Gambar 6.

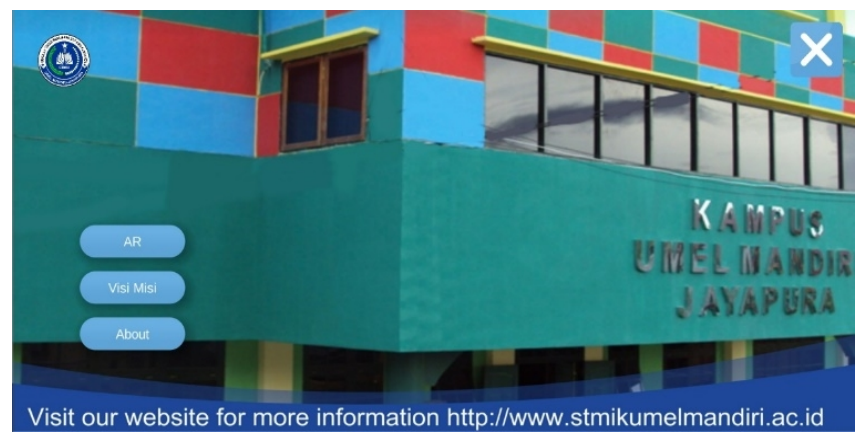

Gambar 6. Tampilan Menu Utama

\subsection{AR}

Menu ini berfungsi untuk memulai menampilkan 3D objek gedung kampus beserta informasi ruangan pada aplikasi AR brosur STMIK Umel Mandiri.

\subsection{Visi Misi}

Menu ini berfungsi untuk melihat informasi mengenai Visi dan Misi STMIK Umel Mandiri seperti pada Gambar 7. 


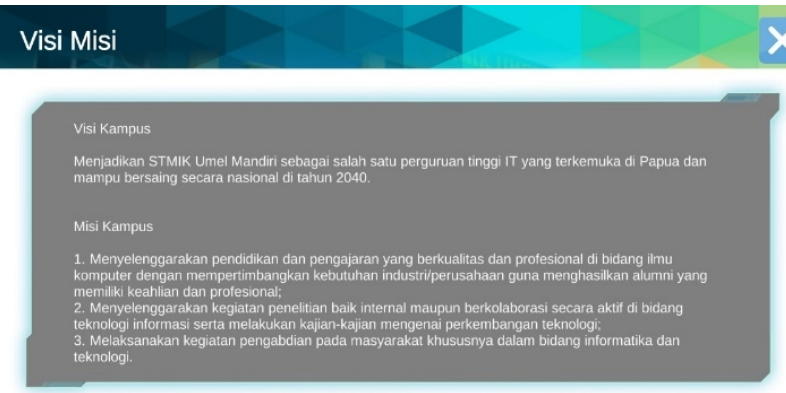

Gambar 7. Tampilan Informasi Visi dan Misi

\subsection{About}

Menu ini berfungsi untuk melihat selayang pandang mengenai STMIK Umel Mandiri, baik dari sejarah perkembangan hingga informasi mengenai Tenaga Pengajar yang ada di STMIK Umel Mandiri seperti pada Gambar 8.

\section{About} X

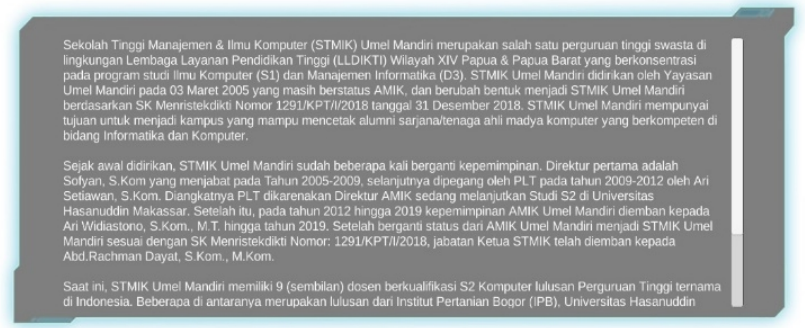

Gambar 8. Informasi About

\subsection{Hidden Link}

Fungsi menu ini untuk menuju ke website STMIK Umel Mandiri, agar pengguna dapat langsung mengakses link Pendaftaran Mahasiswa Baru. Link ini terdapat pada menu utama dan dapat diakses dengan cara melakukan tap/klik pada tulisan http://www.stmikumelmandiri.ac.id seperti pada Gambar 9.

Visit our website for more information http://www.stmikumelmandiri.ac.id

Gambar 9. Hidden Link untuk Akses ke Website STMIK Umel Mandiri

\subsection{Exit}

Menu ini berfungsi untuk keluar dari aplikasi AR brosur STMIK Umel Mandiri.

3. Tahapan Identifikasi Marker

Tahapan ini dimulai saat pengguna aplikasi telah mengarahkan kamera smartphone pada marker yang berupa brosur PMB STMIK Umel Mandri, maka aplikasi AR brosur STMIK Umel Mandiri akan melakukan identifikasi marker. Tampilan identifikasi marker dapat dilihat pada Gambar 10.

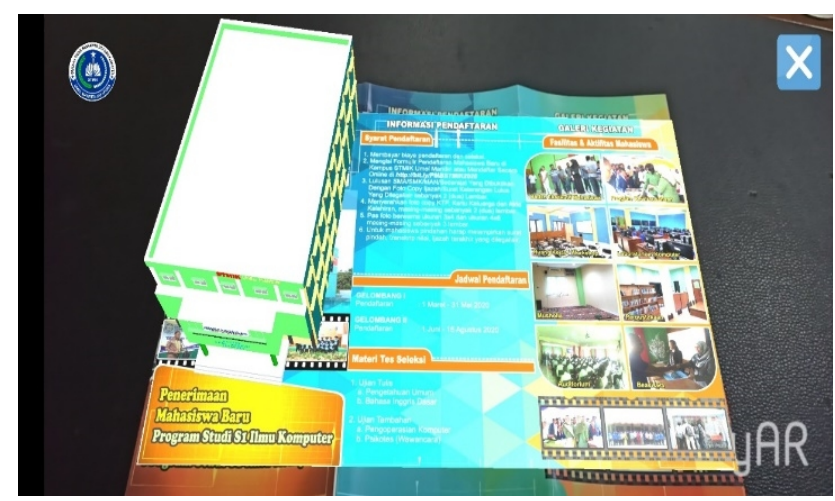

Gambar 10. Objek 3D yang Ditampilkan saat Marker Berhasil Teridentifikasi

Ketika marker teridentifikasi maka objek 3D yang telah dipilih akan muncul di atas marker. Pada saat ini, objek 3D Gedung kampus STMIK Umel Mandiri ditampilkan dengan posisi statis, tidak dapat dirotasi. Untuk dapat melihat denah interior gedung, pengguna harus melakukan double tap/klik pada objek 3D Gedung maka akan tampil informasi seperti pada Gambar 11.

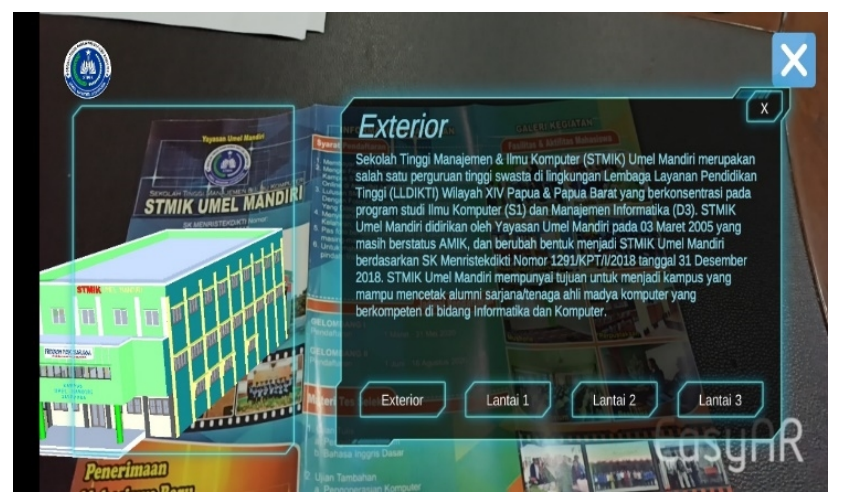

Gambar 11. Tampilan Informasi Gedung STMIK Umel Mandiri

Pada Gambar 11, terlihat beberapa menu yang tersedia, yaitu:

1. Exterior untuk melihat 3D gedung tampak luar,

2. Lantai 1 untuk melihat informasi ruangan dan 3D Lantai 1,

3. Lantai 2 untuk melihat informasi ruangan dan 3D Lantai 2,

4. Lantai 3 untuk melihat informasi ruangan dan 3D Lantai 3. 
Setiap 3D objek yang muncul dapat diperbesar dan dirotasi 360 derajat setelah melakukan double-click pada objek 3D Gedung, seperti terlihat pada Gambar 12.

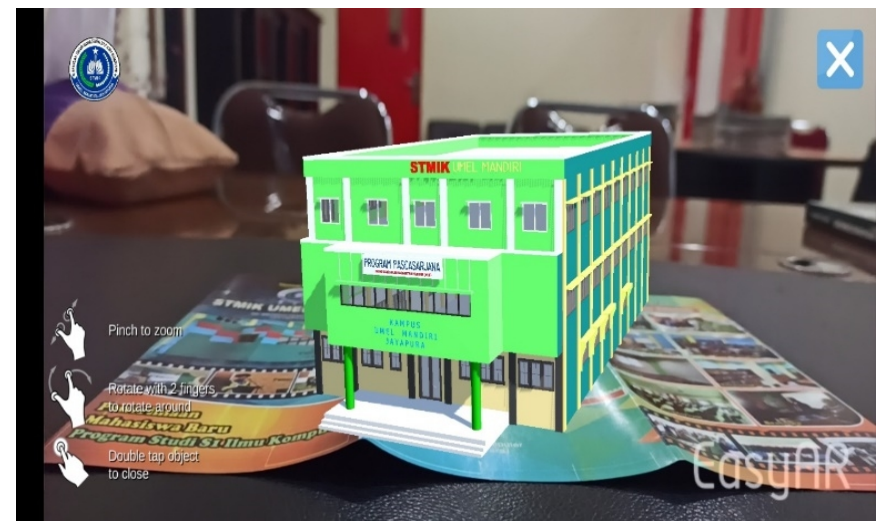

Gambar 12. Tampilan Eksterior 3D Gedung STMIK Umel Mandiri

Untuk saat ini hanya terdapat 4 macam 3D objek yang dihasilkan dalam aplikasi AR brosur STMIK Umel Mandiri, yaitu 3D Gedung Kampus, 3D denah lantai 1,3D denah lantai 2 dan 3D denah lantai 3. Objek 3D yang akan ditampilkan tersebut dapat dilihat pada Gambar 12 dan 13.
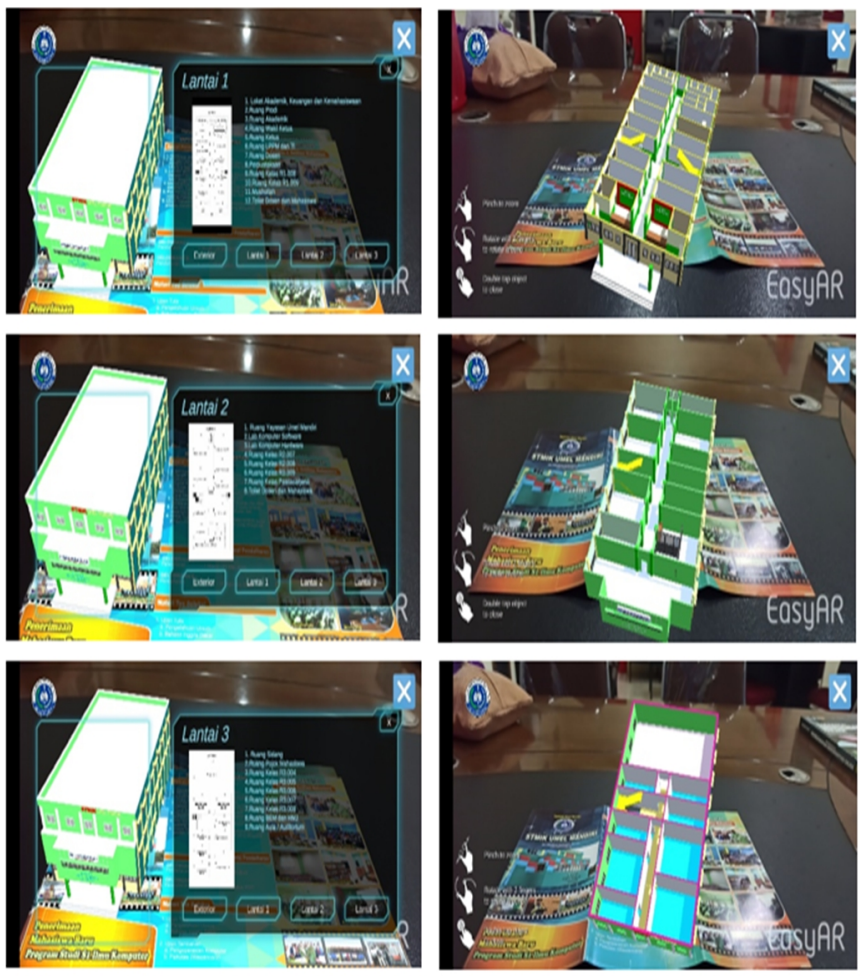

Gambar 13. Tampilan Interior 3D Gedung STMIK Umel Mandiri

\section{Pengujian Sistem}

A. Pengujian Alpha

Tahap awal yang dilakukan dalam pengujian adalah pengujian alpha (alpha test), berupa Blackbox Tes terhadap aplikasi, pelacakan marker terhadap jarak, cahaya, posisi marker, dan beberapa skenario pengujian terhadap marker dan pengujian aplikasi pada beberapa perangkat android, untuk mengetahui satu dan lain hal yang akan berpengaruh saat pendeteksian marker.

1. Pengujian Blackbox

Tabel 1. Pengujian Blackbox

\begin{tabular}{ccc}
\hline Tes Fungsi & Hasil & Keterangan \\
\hline Memunculkan Splash Screen & Berhasil & Berhasil \\
& tampil saat \\
& aplikasi AR \\
& brosur \\
& STMIK Umel \\
& Mandiri dijalankan
\end{tabular}

Antarmuka Pengujian
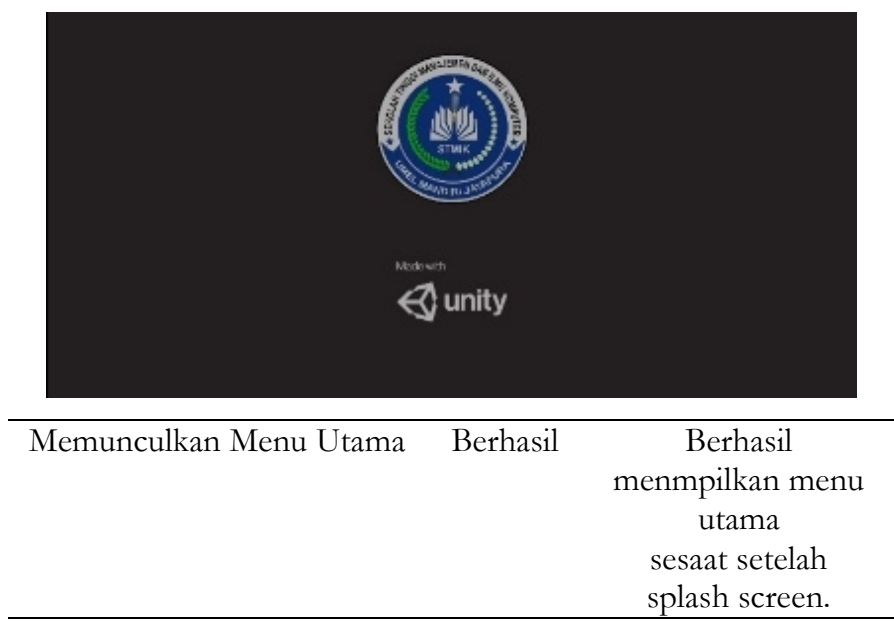
Antarmuka Pengujian

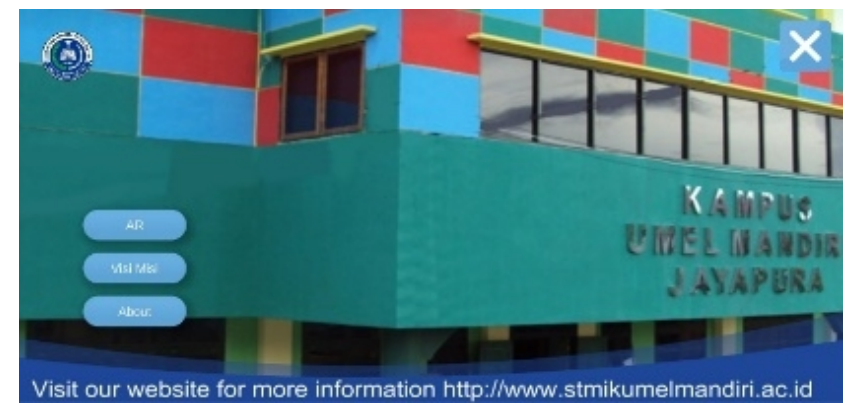

$\begin{array}{ccc}\text { Memunculkan Visi Misi } & \text { Berhasil } & \text { Berhasil } \\ \text { pada Menu Visi Misi } & & \text { memunculkan } \\ & & \text { informasi ketika klik } \\ & \text { menu Visi Misi }\end{array}$




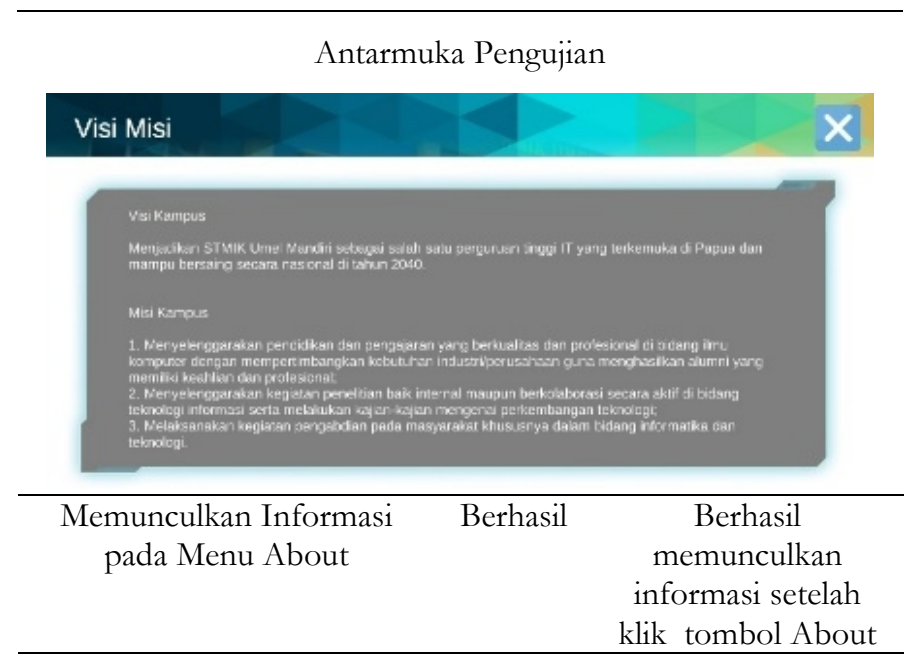

Antarmuka Pengujian

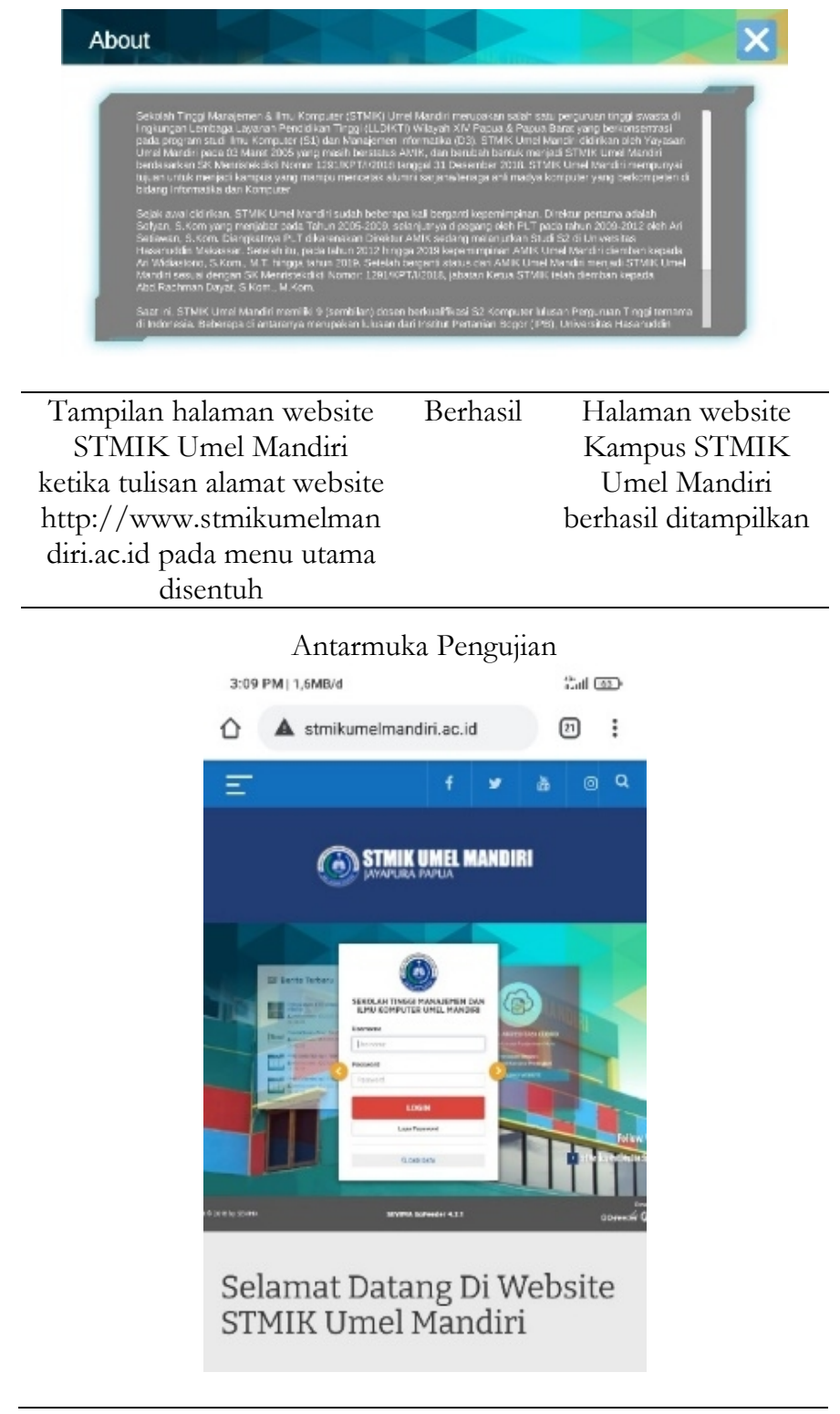

\begin{tabular}{|c|c|c|}
\hline $\begin{array}{c}\text { Memunculkan 3D Objek saat } \\
\text { kamera diarahkan pada marker } \\
\text { AR brosur STMIK Umel } \\
\text { Mandiri }\end{array}$ & Berhasil & $\begin{array}{c}\text { Berhasil } \\
\text { memunculkan } \\
\text { 3D Objek saat } \\
\text { kamera } \\
\text { diarahkan pada } \\
\text { marker }\end{array}$ \\
\hline
\end{tabular}

Antarmuka Pengujian

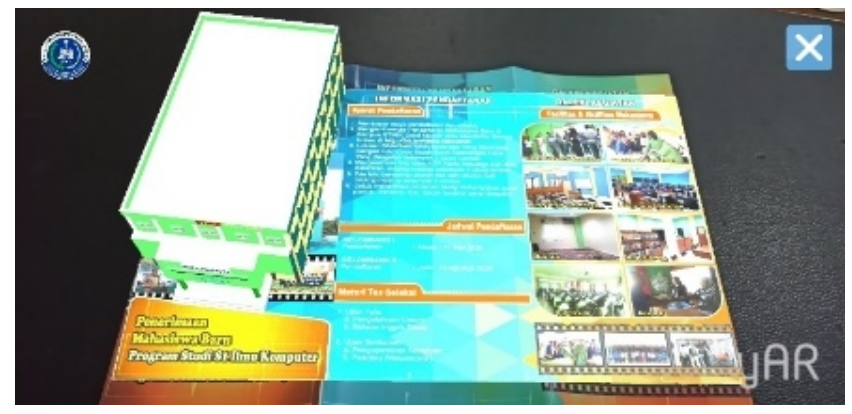

\begin{tabular}{ccc}
\hline $\begin{array}{c}\text { Memunculkan informasi } \\
\text { terhadap 3D objek yang } \\
\text { ditampilkan }\end{array}$ & Berhasil & Berhasil \\
& & $\begin{array}{c}\text { memunculkan } \\
\text { informasi 3D } \\
\text { objek }\end{array}$ \\
\hline
\end{tabular}

Antarmuka Pengujian

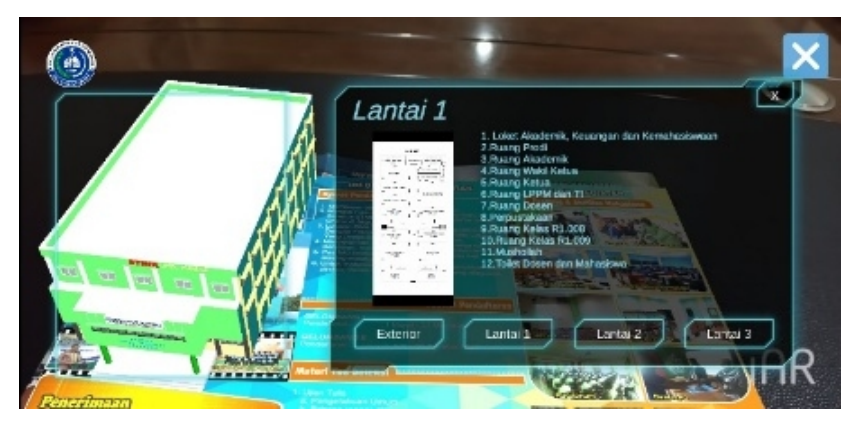

\begin{tabular}{|c|c|c|}
\hline $\begin{array}{l}\text { Tampilkan objek 3D secara full } \\
\text { screen, rotasi dan fungsionalitas } \\
\text { finger-swipe pada objek 3D }\end{array}$ & Berhasil & $\begin{array}{c}\text { Objek 3D } \\
\text { berhasil } \\
\text { ditampilkan } \\
\text { secara full screen, } \\
\text { dapat dirotasi } \\
\text { dan fungsi } \\
\text { finger-swipe } \\
\text { berjalan } \\
\text { sebagaimana } \\
\text { mestinya }\end{array}$ \\
\hline
\end{tabular}

Antarmuka Pengujian

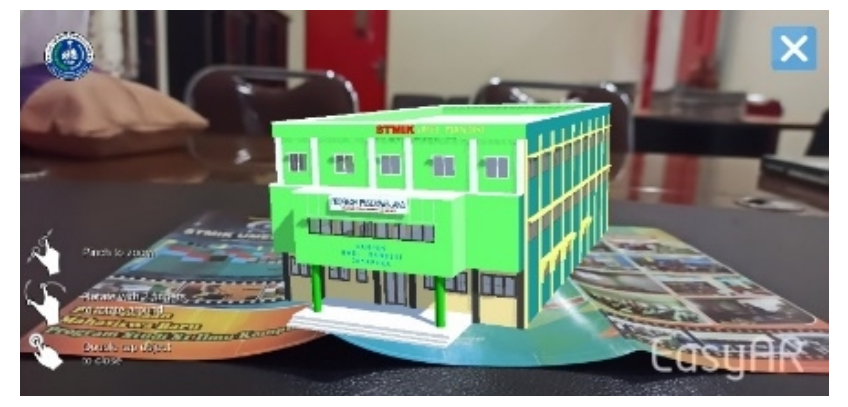


Keterangan:

Berhasil adalah ketika fungsi menu yang dipilih memunculkan 3D objek yang sesuai dengan fungsi yang sudah ditentukan dan berjalan sesuai dengan fungsinya.
2. Pengujian Perangkat Mobile

Pengujian ini bertujuan untuk mengetahui spesifikasi minimum perangkat mobile yang bisa digunakan untuk menjalankan aplikasi AR brosur STMIK Umel Mandiri ini. Hasil dari pengujian perangkat mobile yang digunakan adalah sebagai berikut:

Tabel 2. Spesifikasi Perangkat Mobile

\begin{tabular}{|c|c|c|c|c|c|c|c|}
\hline \multirow[t]{2}{*}{ No. } & \multirow{2}{*}{$\begin{array}{c}\text { Jenis Perangkat } \\
\text { Mobile }\end{array}$} & \multicolumn{6}{|c|}{ Spesifikasi Perangkat Mobile } \\
\hline & & Processor & Chipset & GPU & RAM & Kamera & Operating System \\
\hline 1 & $\begin{array}{c}\text { Samsung Galaxy } \\
\text { Note } 4\end{array}$ & $\begin{array}{c}\text { Processor Octa } \\
\text { Core } 1.3 \mathrm{GHz}\end{array}$ & Exynos 5433 & $\begin{array}{l}\text { Mali-T760 } \\
\text { MP6 }\end{array}$ & $3 \mathrm{~GB}$ & $16 \mathrm{MP}$ & Android 5.1 Lollipop \\
\hline 2 & $\begin{array}{l}\text { Xiaomi Redmi } \\
\text { Note } 8 \text { Pro }\end{array}$ & $\begin{array}{l}\text { Processor Octa } \\
\text { Core } 2.05 \mathrm{GHz}\end{array}$ & $\begin{array}{c}\text { Mediatek Helio } \\
\text { G90T }\end{array}$ & $\begin{array}{l}\text { Mali-G76 } \\
\text { MC4 }\end{array}$ & $6 \mathrm{~GB}$ & $64 \mathrm{MP}$ & Android 10 \\
\hline 3 & $\begin{array}{c}\text { Samsung Galaxy } \\
\text { A60 }\end{array}$ & $\begin{array}{c}\text { Processor Octa } \\
\text { Core 2.0 Ghz }\end{array}$ & $\begin{array}{c}\text { Qualcomm } \\
\text { Snapdragon } 675\end{array}$ & Adreno 612 & $6 \mathrm{~GB}$ & $32 \mathrm{MP}$ & Android 10 \\
\hline 4 & Vivo Y17 & $\begin{array}{c}\text { Processor Octa } \\
\text { Core } 2.3 \mathrm{GHz}\end{array}$ & $\begin{array}{c}\text { Mediatek Helio } \\
\text { P35 }\end{array}$ & $\begin{array}{c}\text { PowerVR } \\
\text { GE8320 }\end{array}$ & $4 \mathrm{~GB}$ & $13 \mathrm{MP}$ & Android 10 \\
\hline 5 & $\begin{array}{l}\text { Xiaomi Redmi } \\
\text { Note } 9 \text { Pro }\end{array}$ & $\begin{array}{l}\text { Processor Octa } \\
\text { Core } 2.3 \mathrm{GHz}\end{array}$ & $\begin{array}{c}\text { Qualcomm } \\
\text { Snapdragon } 720 \mathrm{G}\end{array}$ & Adreno 618 & $8 \mathrm{~GB}$ & $64 \mathrm{MP}$ & Android 10 \\
\hline
\end{tabular}

Tabel 3. Hasil Pengujian pada Perangkat Mobile

\begin{tabular}{ccccccc}
\hline & & \multicolumn{5}{c}{ Hasil Pengujian Aplikasi } \\
\cline { 2 - 6 } No. & $\begin{array}{c}\text { Operation } \\
\text { Processing }\end{array}$ & $\begin{array}{c}\text { Samsung } \\
\text { Galaxy } \\
\text { Note } 4\end{array}$ & $\begin{array}{c}\text { Xiaomi } \\
\text { Redmi Note } \\
8 \text { Pro }\end{array}$ & $\begin{array}{c}\text { Samsung } \\
\text { Galaxy A60 }\end{array}$ & Vivo Y17 & $\begin{array}{c}\text { Xiaomi } \\
\text { Redmi Note } \\
9 \text { Pro }\end{array}$ \\
\hline 1 & $\begin{array}{c}\text { Loading Awal } \\
\text { Aplikasi }\end{array}$ & Berhasil & Berhasil & Berhasil & Berhasil & Berhasil \\
\hline 2 & Proses ke Menu Utama & Berhasil & Berhasil & Berhasil & Berhasil & Berhasil \\
\hline 3 & Proses ke Menu Visi Misi & Berhasil & Berhasil & Berhasil & Berhasil & Berhasil \\
\hline 4 & $\begin{array}{c}\text { Proses } \\
\text { Ke Menu About }\end{array}$ & Berhasil & Berhasil & Berhasil & Berhasil & Berhasil \\
\hline 5 & $\begin{array}{c}\text { Proses ke Menu AR dan } \\
\text { Identifikasi Marker }\end{array}$ & Berhasil & Berhasil & Berhasil & Berhasil & Berhasil \\
\hline 7 & Proses Rotate dan Zoom Objek 3D & Berhasil & Berhasil & Berhasil & Berhasil & Berhasil \\
\hline
\end{tabular}

Dari Tabel 3. tentang pengujian perangkat mobile menjelaskan bahwa semua jenis android dapat menjalankan dan mengoperasikan aplikasi ini dengan lancar. Namun dibutuhkan spesifikasi minimum untuk dapat menggunakan aplikasi ini seperti Processor Quad Core 1,6 GHz, RAM 2GB, kamera 13MP, dan OS Android 4.0 JellyBean.

2. Pengujian Marker

Pengujian ini dilakukan menggunakan 3 jenis perangkat mobile yang berbeda spesifikasi yang mampu menjalankan aplikasi AR brosur STMIK Umel Mandiri dengan baik. Adapun perangkat yang digunakan dalam pengujian yaitu Samsung Galaxy Note 4, Xiaomi Redmi Note 8 Pro, dan Vivo Y17. Pengujian ini menggunakan 1 jenis ukuran marker yang sudah ditetapkan saat pembuatan marker, yakni berukuran A4 $(21 \mathrm{~cm} \mathrm{x}$ $29,7 \mathrm{~cm}$ ) yang mana sesuai dengan ukuran brosur fisik yang telah digunakan. 
Dari pengujian ini, informasi dari tabel akan menjelaskan bahwa diberikan tanda ceklis sebagai penanda marker berhasil terdeteksi dan perangkat android dapat menampilkan 3D objek dengan baik, sedangkan tanda silang menandakan marker gagal dideteksi dengan hasil tidak tampilnya 3D objek.

a. Pengujian Jarak Minimum
Pengujian ini bertujuan untuk memperoleh informasi jarak minimum antara perangkat mobile dan marker. Pendeteksian dilakukan dengan memposisikan kamera smartphone mulai dari posisi tertinggi (skenario marker ditaruh di atas meja) hingga mendekati marker. Pengujian jarak minimum menghasilkan data sebagai berikut.

Tabel 4. Hasil Pengujian Jarak Minimum dari Berbagai Perangkat Android terhadap Marker

\begin{tabular}{|c|c|c|c|c|}
\hline \multirow[b]{2}{*}{ No. } & \multirow[b]{2}{*}{$\begin{array}{l}\text { JARAK } \\
(\mathrm{cm})\end{array}$} & \multicolumn{3}{|c|}{ Perangkat Android } \\
\hline & & $\begin{array}{c}\text { Samsung } \\
\text { Galaxy Note } 4\end{array}$ & $\begin{array}{c}\text { Xiaomi } \\
\text { Redmi Note } 8 \text { Pro }\end{array}$ & Vivo Y17 \\
\hline 1 & 200 & $x$ & $x$ & $x$ \\
\hline 2 & 190 & $x$ & $x$ & $x$ \\
\hline 3 & 180 & $x$ & $x$ & $x$ \\
\hline 4 & 170 & $x$ & $x$ & $x$ \\
\hline 5 & 160 & $x$ & $x$ & $x$ \\
\hline 6 & 150 & $x$ & $x$ & $x$ \\
\hline 7 & 140 & $x$ & $x$ & $x$ \\
\hline 8 & 130 & $x$ & $x$ & $x$ \\
\hline 9 & 120 & $x$ & $\checkmark$ & $\checkmark$ \\
\hline 10 & 110 & $x$ & $\checkmark$ & $\checkmark$ \\
\hline 11 & 100 & $x$ & $\checkmark$ & $\checkmark$ \\
\hline 12 & 90 & $\checkmark$ & $\checkmark$ & $\checkmark$ \\
\hline 13 & 80 & $\checkmark$ & $\checkmark$ & $\checkmark$ \\
\hline 14 & 70 & $\checkmark$ & $\checkmark$ & $\checkmark$ \\
\hline 15 & 60 & $\checkmark$ & $\checkmark$ & $\checkmark$ \\
\hline 16 & 50 & $\checkmark$ & $\checkmark$ & $\checkmark$ \\
\hline 17 & 40 & $\checkmark$ & $\checkmark$ & $\checkmark$ \\
\hline 18 & 30 & $\checkmark$ & $\checkmark$ & $\checkmark$ \\
\hline 19 & 20 & $\checkmark$ & $\checkmark$ & $\checkmark$ \\
\hline 20 & 10 & $\checkmark$ & $\checkmark$ & $\checkmark$ \\
\hline
\end{tabular}

Tabel 5. Hasil Pengujian Sudut Minimum dari Berbagai Perangkat Android terhadap Marker

\begin{tabular}{ccccc}
\hline & & \multicolumn{3}{c}{ Perangkat Android } \\
\cline { 3 - 5 } No. & $\begin{array}{c}\text { SUDUT } \\
\text { (derajat) }\end{array}$ & $\begin{array}{c}\text { Samsung } \\
\text { Galaxy } \\
\text { Note } 4\end{array}$ & $\begin{array}{c}\text { Xiaomi } \\
\text { Redmi Note } \\
8 \text { Pro }\end{array}$ & $\begin{array}{c}\text { Vivo } \\
\text { Y17 }\end{array}$ \\
\hline 1 & 0 & $\checkmark$ & $\checkmark$ & $\checkmark$ \\
\hline 2 & 15 & $\checkmark$ & $\checkmark$ & $\checkmark$ \\
\hline 3 & 30 & $\checkmark$ & $\checkmark$ & $\checkmark$ \\
\hline 4 & 45 & $\checkmark$ & $\checkmark$ & $\checkmark$ \\
\hline 5 & 60 & $\checkmark$ & $\boldsymbol{x}$ & $\mathbf{x}$ \\
\hline 6 & 75 & $\mathbf{x}$ & $\mathbf{x}$ & $\mathbf{x}$ \\
\hline 7 & 80 & $\mathbf{x}$ & $\mathbf{x}$ & $\mathbf{x}$ \\
\hline 8 & 90 & $\mathbf{x}$ & $\mathbf{x}$ & \\
\hline
\end{tabular}

Dari Tabel 4. tentang pengujian jarak minimum didapatkan informasi bahwa ukuran piksel pada lensa kamera smartphone Android berpengaruh terhadap daya tangkap pendeteksian marker yang digunakan. Semakin jauh jarak dari marker yang dapat dikenali, maka semakin besar ukuran piksel lensa kamera yang dimiliki. Adapun ukuran 3D yang ditampilkan ketika jarak semakin jauh maka 3D objek yang ditampilkan tampak kecil (tidak seperti ukuran aslinya), dan ketika jarak antara kamera dan marker didekatkan maka 3D objek yang ditampilkan tampak lebih besar. Dari data 
tersebut dapat disimpulkan bahwa jarak terbaik bagi perangkat mobile untuk mendeteksi marker dengan menggunakan perangkat pengujian (Samsung Galaxy Note 4, Xiaomi Redmi Note 8 Pro, dan Vivo Y17) adalah 20-50 cm.

\section{b. Pengujian Sudut Minimum}

Pengujian ini dilakukan untuk menguji sudut minimum yang dibutuhkan untuk mengidentifikasi marker. Sudut yang digunakan dimulai pada sudut 00 terhadap sumbu Y dikarenakan marker menghadap vertikal (ke atas). Hasil pengujian sudut minimum diperoleh hasil yang ditunjukkan pada Tabel 5 .

Dari Tabel 5. tentang pengujian sudut minimum menjelaskan bahwa sudut maksimum marker masih terdeteksi adalah $60^{\circ}$. Di atas sudut $60^{\circ}$ sudah tidak dapat terdeteksi lagi yaitu sudut $75^{\circ}, 80^{\circ}$ dan $90^{\circ}$ baik itu menggunakan Samsung Galaxy Note 4, Xiaomi Redmi Note 8 Pro maupun Vivo Y17. Adapun sudut terbaik untuk menampilkan objek 3D adalah sudut $30^{\circ}$ $-60^{\circ}$.

B. Pengujian Beta

Pengujian Beta merupakan pengujian aplikasi AR Brosur STMIK Umel Mandiri terhadap pengguna aplikasi. Saat pengujian ini, peneliti mendapatkan 15 orang yang bersedia menggunakan aplikasi AR Brosur STMIK Umel Mandiri, kemudian memberikan korespondensi dalam bentuk kuesioner.

Tabel 6. Hasil Kuesioner Penggunaan Aplikasi AR Brosur STMIK Umel Mandiri

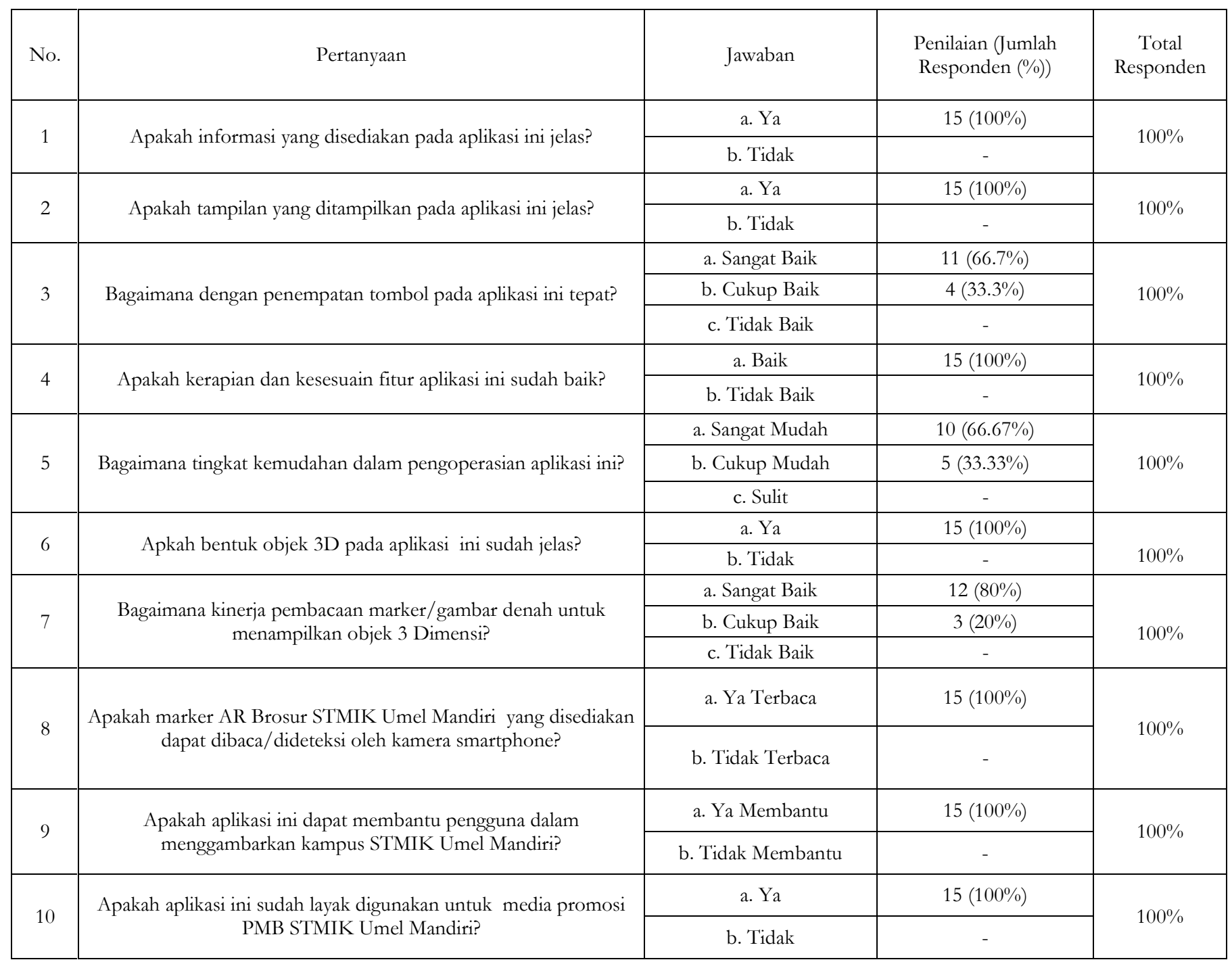


Berdasarkan Tabel 5, dapat disimpulkan bahwa semua responden (15 orang) merasa mudah dalam menggunakan dan mengoperasikan aplikasi, jelas terhadap tampilan dan informasi yang disediakan pada aplikasi ini, serta responden juga merasa aplikasi ini dapat membantu dalam menjelaskan tentang kampus STMIK Umel Mandiri, baik dari lokasi, keadaan gedung dan ruangan serta informasi tentang sejarah dan visi misinya. Sehingga 15 orang responden ini sepakat jika aplikasi ini dimanfaatkan sebagai media promosi kampus STMIK Umel Mandiri. Dari pengujian beta tersebut, dapat disimpulkan bahwa penelitian ini telah menghasilkan sebuah aplikasi berbasis teknologi augmented reality yang digunakan untuk membantu mempromosikan Kampus STMIK Umel Mandiri melalui perangkat dengan sistem operasi android.

\section{KESIMPULAN}

Aplikasi AR brosur STMIK Umel Mandiri telah dibangun berdasarkan kebutuhan perguruan tinggi agar tetap memberikan informasi secara interaktif. Aplikasi ini mampu menampilkan informasi seputar kampus STMIK Umel Mandiri, mulai dari Visi dan Misi, Selayang Pandang, Informasi Lokasi dan 3D Gedung beserta informasi dari ruangan setiap lantai. Augmented Reality Gedung Kampus STMIK Umel Mandiri dapat ditampilkan dengan baik dengan menggunakan marker yang berupa brosur fisik. Dari hasil pengujian marker, kamera dapat mengenali marker dengan baik pada jarak $5 \mathrm{~cm}-90 \mathrm{~cm}$, namun jarak ideal adalah pada jarak $15 \mathrm{~cm}$. Adapun sudut terbaik kamera terhadap marker adalah dari $0^{\circ}$ secara vertikal hinggal $60^{\circ}$. Dan berdasarkan hasil pengujian aplikasi terhadap 15 user/responden merasa mudah dalam menggunakan dan mengoperasikan aplikasi, jelas terhadap tampilan dan informasi yang disediakan pada aplikasi ini. Oleh karena itu, semua responden sepakat jika aplikasi ini dimanfaatkan sebagai media promosi kampus STMIK Umel Mandiri.

\section{UCAPAN TERIMA KASIH}

Terima kasih kepada Kementerian Riset dan Teknologi/Badan Riset dan Inovasi Nasional Deputi Bidang Penguatan Riset dan Pengembangan yang telah memberikan Dana Hibah Penelitian skema Penelitian Dosen Pemula Tahun Anggaran 2020.

\section{DAFTAR PUSTAKA}

[1] Tri Yuliati, Ema Utami, dan Hanif Al Fatta. 2014. Perancangan Mobile Augmented Reality dengan Metode Interactive Multimedia System Design Development (Studi Kasus: Brosur di Sekolah Tinggi Teknologi Dumai). Jurnal Dasi. Volume 15 No. 1, Hal. 54-60.

[2] Latius Hermawan dan Mochamad Hariadi Pemanfaatan. 2015. Augmented Reality Sebagai Media Informasi Kampus Menggunakan Brosur. Seminar Nasional Teknologi Informasi dan Komunikasi 2015 (SENTIKA 2015) Volume 1 No. 1, Hal. 81-88.

[3] AR Dayat, A Michael, dan L Angriani. 2015. Pengaturan Tata Letak Furniture Menggunakan Augmented Reality. Jurnal IT. Volume 6 No. 1, Hal. 36-41.

[4] R Wirawan. 2019. Implementasi Augmented Reality pada Transformasi Sistem Promosi Kampus STMIK Bina Adinata. Jurnal INSTEK. Volume 4 No. 2, Hal. 265-272.

[5] Miftahul Madani, Arief Setyanto, dan Amir Fatah Sofyan. 2018. Penerapkan Augmented Reality pada Media Promosi (Brosur) STMIK Bumigora Mataram Berbasis Android. Jurnal Teknologi Informasi. Volume 13 No. 3, Hal. 108-115.

[6] AR Dayat dan L Angriani. 2020. Perancangan Model Pengenalan Kebudayaan Papua Secara Interaktif Berbasis Android. JISKA (Jurnal Informatika Sunan Kalijaga). Volume 5 No. 1, Hal. 42-55.

[7] Safaat H, Nazruddin. 2012. Pemrograman Apliaksi Mobile Smartphone dan Tablet PC Berbasis Android. Informatika: Bandung.

[8] S Amin. 2020. Perancangan Aplikasi Pengenalan AlatAlat Praktik Laboratorium Kimia Berbasis Augmented Reality. Syntax Literate: Jurnal Ilmiah Indonesia. Volume 5 No. 8, Hal. 681- 694.

[9] AS Laswi dan A Andryanto. 2018. Implementasi Augmented Reality Pada Museum Batara Guru Kompleks Istana Langkanae Luwu. ILKOM Jurnal Ilmiah. Volume 10 Nomor 2, Hal. 144-151.

[10] Murya, Yosef. 2014. Pemrograman Android Black Box. Jasakom: Jakarta. 